\title{
Cost Performance Assessment of High Rise Hospital Building Construction Project
}

Dr. Anjay Kumar Mishra ${ }^{1 *}$, Er. Lalit Koju ${ }^{2}$

${ }^{1}$ Associate Professor and Research Director, Madan Bhandari Memorial Academy Nepal, Urlabari 3, Morang, Nepal

${ }^{2}$ Hydro-Consultant Engineering Pvt.Ltd

\begin{tabular}{|c|c|}
\hline $\begin{array}{c}\text { Article History } \\
\text { Received: } 26.08 .2020 \\
\text { Accepted: } 17.09 .2020 \\
\text { Published: } 30.09 .2020 \\
\text { Journal homepage: } \\
\text { https://www.easpublisher.com/easjebm } \\
\end{array}$ & $\begin{array}{l}\text { Abstract: Cost is one of most important aspects of all type of construction. This research } \\
\text { has been designed to study the cost performances of Hospital for Advanced Medicine } \\
\text { and Surgery (HAMS) Kathmandu building construction project. In this research the } \\
\text { proposed work schedule was compared with actual work progress in site and the } \\
\text { estimated cost of the work was compared with the actual cost. The responses from a } \\
\text { questionnaire survey and review of records from concerned representative were } \\
\text { examined to identify the factor affecting the performance of building construction. The } \\
\text { factor affecting the performance was identified and presented in various ways for the } \\
\text { interpretation. Out of } 23 \text { activities, } 14 \text { activities got delayed. The total number of days } \\
\text { delayed was } 16 \text { days out of } 80 \text { days. The reasons were low numbers of labors, rain, } \\
\text { change in design, deficiency of material, poor working conditions, non-confidence in } \\
\text { workers and poor performance of machinery. The quantity of formworks, M } 25 \text { concrete } \\
\text { and steel got exceeded by } 2360.72 \text { sqft, } 1820.28 \text { cuft and } 3561.36 \text { kg respectively due to } \\
\text { change in design. The total excess in cost was } 1,668,004.824 \text { rupees which was } \\
12.58 \% \text { of total cost. Effective and efficient training courses for engineers in } \\
\text { scheduling, cost, productivity, information systems and management of human } \\
\text { resources must be conducted. The study quality and safety would not have been } \\
\text { compromised. Good performance of any construction project refers to continuous } \\
\text { improvement of the project activities to achieve the project objectives in terms of time, } \\
\text { cost, quality, safety and ethics. Further research should be designed to study the } \\
\text { construction performances of Hospital for Advanced Medicine and Surgery (HAMS) } \\
\text { building construction project based on quality control and safety. } \\
\text { Keywords: Schedule, Cost Variation, Schedule variation, Delays, Factors. }\end{array}$ \\
\hline
\end{tabular}

Copyright $\odot$ (2020 The Author(s): This is an open-access article distributed under the terms of the Creative Commons Attribution 4.0 International License (CC BY-NC 4.0) which permits unrestricted use, distribution, and reproduction in any medium for non-commercial use provided the original author and source are credited.

\section{INTRODUCTION}

A "construction project" is a high value, time bound, special construction mission of creating a construction facility or service, with predetermined performance objectives defined in terms of quality specification, completion time, budgeted cost and other specified constraints [1]. Construction industry is complex in nature because it contains large number of project parties as clients, consultants, contractors, stakeholders, shareholders and regulators. Poor construction performance has created economic situation which the industry cannot manage and at the same time the industry stakeholders or contractors do not know how to document these problems for future references. The construction industry performance is affected by national economies [2]. Successful building construction projects are those projects finished on time, within budget, in accordance with specifications and to stakeholders' satisfaction [3-5]. Particular emphasis has been given to reducing construction schedules and many causes have changed the core concept of traditional construction management and methods [6]. Completion of project on time and absence of the cost overrun are considered the most important factor of the successful projects.

Life safety code defines a high rise building as a building more than $75 \mathrm{ft}(22.5 \mathrm{~m})$ in height where building height is measured from the lowest level of fire department vehicle access to the floor of the height occupiable story [3] High rise buildings present several unique challenges which are not found in traditional low rise buildings due to parameters like longer egress time and distance, evacuation strategies, fire department accessibility, smoke movement and fire control [8]. Hospital for Advanced Medicine and Surgery (HAMS) construction project is situated at Mandikhatar, Kathmandu. It is also one of the high rises building construction project since building height is $38.15 \mathrm{~m}$. This project firstly started for apartment provision.But due to different reasons this building project is now a 
hospital project. The construction work was stopped for 2 years after the earthquake of 2015. The plinth area of this building is $1170.75 \mathrm{sq} \mathrm{m}$. This is a ten stories building including a helipad.

If a'non-personal residential' structure is to be constructed, the approval from the Department of Urban Development and Building Construction (DUDBC) must be taken [9]. Nepal is a country that stands at $11^{\text {th }}$ rank in the world with respect to vulnerability toearthquake [10]. Many high rises building in Nepal is not being completed within time and estimated cost. There may be the various reasons for it. Finding out the main causes for the variation in time and may help successful completion of upcoming future high rise building construction projects.

\section{RESEARCH OBJECTIVE}

The present study was designed to access the building construction practices by studying work schedule variation and the factors affecting the project performance and assess the variation on cost the building construction taking Hospital for Advanced Medicine and Surgery (HAMS) building construction as a case study.

\section{Literature REVIEW}

\section{Time overrun and cost overrun in project}

In construction, delay could be defined as the time overrun either beyond completion date specified in a contract, or beyond the date that the parties agreed upon for the delivery of a project. It is a project slipping over its planned schedule and this is a common problem in construction projects. Completing projects on time is an indicator of efficiency, but the construction process is subject to many variables and unpredictable factors, which result from many sources. The sources are the performance of parties, resources availability, environmental conditions, involvement of other parties, contractual relations, and the completion of a project within the specified time is rare [11]. Any construction project comprises two distinct phases: the preconstruction phase (the period between the initial conceptions of the project to awarding of the contract) and the construction phase (period from awarding the contract to when the actual construction is completed). Delays and cost overruns occur in both phases. However the major instances of project overruns usually take place in the construction phase [12].

Cost and schedule overruns occur due to wide range of factors. If project costs or schedules exceed their planned targets, client satisfaction would be compromised. The funding profile no longer matches the budget requirement and further slippage in the schedule could result [13]. Frimpong, et al. [12] revealed that project management tools and techniques play an important role in the effective management of a project. Project management involves managing the resourcesworkers, machines, money, materials and methods used.

Construction delays are more likely to happen in almost all projects due to the miscommunicationbetween contractors, subcontractors, propertyowners or any other reasons. In many cases, construction projects are delayed because of inaccurate estimate of time and project cost that was initially presented to the clients or project owners. Delays and cost overruns are the most common problems causing delay in the construction industry in both developed and developing countries [14]. A study by Flyvbjerg [15] exposed that nine out of ten projects had the cost overruns from a sample of 258 companies across 20 countries and 5 continents around the world. In practice, delays occur in every construction project and the magnitude of these delays varies significantly from project to project and country to country [16].The cost overruns consequence could be more serious and the results could sometimes exceeds $100 \%$ of the initial project estimated [17]. Kaming, et al. [18] conducted a study on thirty one high rise projects in Indonesia, and the study revealed that the cost overruns are more likely to occur than time overruns, which means that the issue of cost is more important and common than the project delay. He found that majority of the problem causing cost overruns are due to increase in material prices and currency inflation, whereas the delay in time was due to inaccurate estimation, design changes, poor labor productivity, inadequate planning, and shortages of necessary resources

The past project history shows that the construction industry has vast number of projects were completed with time and cost overrun [19]. Al-Momani [20] suggested that the actual estimated cost of project rises by up $30 \%$ by the time the project is ready to be completed even in the most developing countries. There were three main causes of cost overruns identified in a study in Kuwait, which include contractor related problems, material related problems and owners' lack of experience [21]. Jahren [22] discovered that the quality of the contractor document, nature of the interpersonal relation on the project andthe policies of the contractor were key factors causing a significant impact on cost overruns. The same investigation also exposed that a cost overrun rate from $1 \%$ to $11 \%$ are more likely to occur on larger construction projects than smaller ones. Nonetheless, Yates [23] suggested that non-compensable delay occurs due to acts of God where the fault are not from any parties and therefore, the contractor is entitled only to extension of time but not additional cost.

According to Rabbani, et al. [24], the most common factors that cause the construction delay in Pakistan are external factors due to natural disaster such as earthquake and floods. Similarly, Bramble and Callahan [25] found that unexpected problem such as 
act of natural phenomenon also causes the project delay. Other factors causing delay in Pakistan are financial payment issues, poor planning, poor site management, lack of experience and shortage of materials and equipment. In other hand, the main reasons for delay in Saudi Arabia are due to the lack of qualified man power in the industry [26]. In another study by Sriprasert [27] highlighted that the main reason of project delay and cost overruns is the lack of capability of controlling the construction processes in Thailand.A study was conducted by Battaineh [28] within164 buildings and 28 highway projects constructed in Jordan during the period of 1996-1999, and he revealed that the actual completion period increased by $160 \%$ in road construction projects and $120 \%$ in building projects compare to the initial estimated time. This is because of the project complexity in nature and varies from one location to another location geographically in the world and the issues of delay and cost overruns are common, particularly in the construction projects in the developing countries. Moreover, Assaf [11] conducted similar study in the Saudi Arabia and he exposed that only $30 \%$ of construction projects were completed on time and $70 \%$ project were delay whereas the cost overrun was between $10 \%$ and $30 \%$ which leaves a significant proportion of delay in the country.

\section{Factors Affecting Schedule Overrun}

Several studies have addressed many different factors that cause overruns in different types of construction projects. Generally Construction delay is considered to be one of the most recurring problems in the construction industry and it has an adverse effect on project success in terms of time, cost, quality, and safety.Causes of schedule overruns are factors that lead to construction projects not being finished according to the planned scheduled time at the inception of project.

Haseeb, et al. [29] mentioned the thirty-seven factors that cause delay and their effects on the success and completion of project and grouped into seven groups. The most common factor of delay is natural disaster in Pakistan like flood and earthquake and some others like financial and payment problems, improper planning, poor site management, insufficient experience, shortage of materials, and equipment.

Ade-ojo and Babalola [30] stated that there are 6 major causes that would lead to schedule overruns, the identified causes were ranked as follows: design error, poor site condition, delay in payment, financial incapability of client, financial incapability of contractor and non-availability of subcontractor and supplier.

Akinsiku and Akinsulire [31] showed that financial or cash flow difficulties, financial difficulties faced by contractors and public agencies, frequent change order and design, failure to pay for completed works, shortages of resources, considerable additional work, escalations of material prices, increases in the scope of work, delay in design work and late delivery of materials are the top ten causes of schedule overruns on construction projects.

Ali, et al. [32] showed that labor shortage, contractor's financial difficulties, construction mistakes and defective works, coordination problem, material shortage and poor Site management are the major factors that contribute to schedule overruns con construction projects in Malaysia.

Memon, et al. [33] revealed that design and documentation issues, financial resource management, project management and contract administration, contractors site management, information and communication technology, material and machinery resource, labor (human) resource and external factors as the major factors affecting time performance on construction projects.

The study of Pourrostam and Ismail [34] showed the following as the top ten causes of schedule overruns: poor site management, delay in progress payments by client, change orders by client during construction, ineffective planning and scheduling of project by contractor, financial difficulties by contractor, slowness in decision making process by client, delays in producing design documents, late in reviewing and approving design documents by client, poor contract management by consultant and problems with subcontractors.

Algharbi et al. [35] examined the factors behind the delay in construction projects in Malaysia. Results showed that the financial issue is the dominating factor among other factors that cause the delay of construction project in Malaysia. Coordination problems came next after the financial factor followed by materials problems. Al-Moumani [36] identified poor design and change orders as the leading causes of delay in Jordan. Koushki et al. [21] regarded changing orders and owner financial concerns as the top factors affecting delays in the Kuwaiti construction industry.Faridi and Al Sayegh [37] recognized that slow preparation of drawing was a major factor affecting delay in the United Arab Emirates construction sector. Kaming, et al. [18] investigated that design changes, materials shortage and inadequate planning were the most significant contributors to time delays on construction projects. Similarly, Sambasivan \& Soon [38] divided their findings into client, contractor and consultant categories, with all three categories listing, poor site management, inadequate contractor experience and poor subcontractors among the top five causes for time delays on construction projects. Ogunlana, et al. [4] investigated 12 high rise buildings and differentiated their findings into client/consultan treated, contractorrelated and external causes for time delays. The 
weighted findings among these three categories indicated that material shortages, overstretching of technical personnel and design changes were the most important causes for project delays. Walker [39] surveyed Australian project representatives and found that the most important factors that affect time delays are the ability of the organization to manage risk, planning capabilities and effective resource coordination. Kumaraswamy \& Chan [40] studied time delays on Hong Kong projects and found that, unforeseen ground conditions, poor site management and slow speed of decision-making were the most prominent causes of time delays. The results from a study of 130 public projects in Jordan by Al-Momani [41] indicated that poor design and negligence by the owner, change orders and poor weather and site conditions contributed most to delays.

Jaskowski and Biruk [42] pointed out that project activities' durations are directly affected by different risk factors independently. Every activity within the project has its own time and cost estimates with different processes differentiating the type of work undertaken to accomplish these activities. All differ and affected by different risk factors that might have a major impact on one and slightly affect the other. The causes and effects of delay factors in construction industry vary from country to country due to environmental, topographical and technological constraints. In anticipation of the effect of globalization and the technological difference between developing and developed countries, it is necessary to identify the actual reasons of delay in order to reduce the impact of delay in any construction project [43].

\section{Factors influencing cost overruns}

Morris [44] investigated some factors that influence cost overrun of construction projects such as inadequate project planning, delay in construction, change in scope of the project, planning and implementation, supply of raw materials and equipment by contractors, resource constraint: power, funds, associated auxiliaries, foreign trade not ready and delay in decision making by government, failure of specific coordinating bodies.

Elinwa and Buba [45] performed a survey in Nigeria. Material cost, fraudulent practices, material price increment, high cost of machines and poor planning were found as the peak cause of cost overruns.

Flyvbjerg [46] investigated about the actual cost and estimated cost in public work project. His aim was to find if there is any difference between actual cost and estimated cost. He has undergone various methods and found that the difference between actual cost and estimated cost is due to technical factors, economic factors, psychological factors and political factors. From factors he concluded that in every infrastructure project, the actual cost will be higher than estimated cost. He added that the cost under estimation occur not only by error and mostly by strategic misrepresentation.

Bubshait and Al-Juwairah [47] examined 42 main factors influencing the construction cost in Saudi Arabia. From identifying their degree of importance by using severity index for owners, consultants, contractors and combination of respondents, the study concluded that incorrect planning, poor financial control on site, inexperience in managing contracts, materials cost, are factors that contribute to high construction costs.

Jackson [48] performed a study on building projects in UK. Most important factors causing cost overrun are poor project planning and management, unexpected ground conditions, lack of information, design development, estimating method, procurement route, commercial pressure, time limit and external factor.

Omoregie and Radford [49] studied the factors influencing cost overrun of infrastructure projects in Nigeria. The major factors of cost overruns imported materials and plant items, additional works, shortage of materials, inaccurate estimate, nominated suppliers and subcontractors, non-adherence to contract conditions, mistakes and discrepancies in contract condition, mistakes and discrepancies in contract conditions, design changes, weather, mistakes and discrepancies in contract condition and are price fluctuation, financing and payments of complete works, poor contract management, schedule delay, changes in site condition and fraudulent practices.

Le-Hoai, et al. [50] found five significant factors influencing cost overruns in Vietnam such as financial difficulties of owner, poor site management and supervision, poor project management assistance, financial difficulties of contractors, design changes.

Enshassi, et al. [14] analyzed the major factors causing cost overruns which includes fluctuations in the cost of building materials, increment of materials prices due to continuous border closures, delay in construction, supply of raw materials and equipment by contractors, unsettlement of the local currency in relation to dollar value, project materials monopoly by some suppliers, resources constraint, lack of cost planning/monitoring during pre-and post- contract stages, funds and associated auxiliaries not ready, design changes, improvements to standard drawing during construction stages and inaccurate quality takeoff. A questionnaire survey was carried out by Ali and Kamaruzzaman [51] and the most serious factor contributed to cost overrun was inaccurate or poor estimation of original cost. The most significant method to control construction cost is proper project costing and financing. He concluded that the problem of cost overrun is not a small issue and it could cause serious problems to the construction industry. 
Olawale [52] identified 21 major factors causing cost overruns in UK. The major factors are design changes, incorrect evaluation of projects time and cost, risk and uncertainty related with projects, nonperformance of subcontractors, conflict between project parties, fluctuation of rates, low skilled manpower, financing and payment, unstable interest rate, complexity of works, lack of proper training and experience of project manager, disagreement in contract documentation, lack of appropriate software, inflation of prices, contract and specification interpretation disagreement, dependency on imported materials, unpredictable weather condition, projects fraud and corruption, weak regulation and control and unstable government policies.

Durdyev, et al. [53] identified 40 factors in Turkey that causes cost overrun in construction of residential projects. The major factors are improper planning, inaccurate project cost estimation, high cost of needed resources, lack of skilled workforce, price of construction materials and high land prices.

Kasimu [54] found a qualitative research approach to obtain vital information of the major factors causing cost overrun in the building construction projects. The factors were ranked according to the degree of significance as assessed by the respondents and shows that the major causes of cost overruns are materials price fluctuation, lack of experience in contracts works, insufficient time, and incomplete drawings. Mishra et al. (2020) gave a formula to predict time and cost for building project as An equation, $T=487.5 \times(C / 79.96) 0.293$ where time is expressed in days and cost in million NRs.

\section{Methodology}

\section{Research design}

This research identified the performance of construction of HAMS building project in terms of time and cost. In this research, qualitative approach was used to find the factors influencing the performance on construction of HAMS building project. Quantitative approach was used to understand the saving in cost. The parties involved in this construction were HAMS management team as a client, Design Cell Pvt. Ltd. as the consultant, Religare Construction Pvt. Ltd. as a contractor. All the related architectural and structural drawings, rate, schedule of work etc were collected from client, consultant and contractor for the analysis. In this study, the detail documents of proposed schedule and estimated cost were collected.

Technical, financial and other related documents were collected from Design Cell Pvt. Ltd., Religare Construction Pvt. Ltd. and HAMS management team as secondary data.

\section{Data Analysis}

- All the activities of the proposed schedule were compared with the actual schedule of site. The varied activities with varied number of days were noticed and noted. The factors for variation in proposed and actual schedule were noted. The most frequent factors were taken as prominent factors and least frequent factors were taken as less important factors for schedule variance.

\section{Summary of Research Methodology}

Table-1: Research Methodology

\begin{tabular}{|l|l|l|l|l|l|}
\hline Objectives & Indicators & Data required & $\begin{array}{l}\text { Collection } \\
\text { tools }\end{array}$ & Analysis & $\begin{array}{l}\text { Expected } \\
\text { outcomes }\end{array}$ \\
\hline $\begin{array}{l}\text { Schedule } \\
\text { analysis }\end{array}$ & $\begin{array}{l}\text { Planned and actual } \\
\text { work comparison }\end{array}$ & $\begin{array}{l}\text { Both the } \\
\text { schedule }\end{array}$ & $\begin{array}{l}\text { Project } \\
\text { document }\end{array}$ & $\begin{array}{l}\text { Comparison with } \\
\text { planned schedule }\end{array}$ & Variation \\
\hline Cost analysis & $\begin{array}{l}\text { Estimated and actual } \\
\text { cost }\end{array}$ & $\begin{array}{l}\text { Quantity of } \\
\text { item change }\end{array}$ & $\begin{array}{l}\text { Official data } \\
\text { (Client) }\end{array}$ & $\begin{array}{l}\text { Comparison with } \\
\text { estimated cost }\end{array}$ & Variation \\
\hline
\end{tabular}

\section{RESUlTS AND DisCUSSIONS}

\section{Variation in schedule}

The direct observation was made for confirmation of work item delay and reasons behindwere noted (Table 2). 
Table-2: Work item delay with the reasons

\begin{tabular}{|l|l|l|l|l|l|l|l|l|l|}
\hline & & & \multicolumn{7}{|c|}{ Reasons for variance } \\
\hline & W.N. & LNL & Rain & CD & DOM & PWC & NCW & PPM \\
\hline 1 & Casting of Level 4 Column & & $\checkmark$ & & & & & \\
\hline 2 & Formwork for Level 5 Slab & $\checkmark$ & & $\checkmark$ & $\checkmark$ & & & \\
\hline 3 & Steel Work for Level 5 Slab & $\checkmark$ & & $\checkmark$ & $\checkmark$ & & & \\
\hline 4 & Scaffolding for double height floor & $\checkmark$ & & & $\checkmark$ & & & \\
\hline 5 & Formwork for double floor height Slab & $\checkmark$ & & & & $\checkmark$ & & \\
\hline 6 & Steel Work for Level 5 Slab & $\checkmark$ & & & & $\checkmark$ & & \\
\hline 7 & Formwork for Level 6 Slab & $\checkmark$ & $\checkmark$ & $\checkmark$ & & & $\checkmark$ & \\
\hline 8 & Steel Work for Level 6 Slab & $\checkmark$ & $\checkmark$ & & & & $\checkmark$ & \\
\hline 9 & Casting of Level 6 Slab & & $\checkmark$ & & & & & $\checkmark$ \\
\hline 10 & Steel and formwork in column of Level 6 & $\checkmark$ & $\checkmark$ & & & & & \\
\hline 11 & Casting of Level 6 Column & $\checkmark$ & $\checkmark$ & & & & & \\
\hline 12 & Formwork for Level 7 Slab & $\checkmark$ & $\checkmark$ & & & & & \\
\hline 13 & Steel Work for Level 7 slab & $\checkmark$ & $\checkmark$ & & & & & \\
\hline 14 & Casting of Level 7 Slab & & $\checkmark$ & & & & & $\checkmark$ \\
\hline Summation & 11 & 9 & 3 & 3 & 2 & 2 & 2 \\
\hline
\end{tabular}

$\mathrm{LNL}=$ Low number of Labors

$\mathrm{CD}=$ Change in design

$\mathrm{DOM}=$ Deficiency of materials

PWC $=$ Poor working condition

$\mathrm{NCW}=$ Non confidence in workers

$\mathrm{PPM}=$ Poor performance of machinery

Out of 23 activities, 14 activities were delayed. The reasons for the activities affected were indicated by $\checkmark^{\prime}$ in the intersected grid of Table 4.1.Out of 14 delayed activities, 11 activities were affected by low numbers of labors; 9 activities were affected by rain; 3 activities were affected by change in design; 3 activities were affected by deficiency of material and 2 activities were affected by poor working condition, nonconfidence in workers and poor performance of machine. Because of religious, cultural and agricultural duties of labors the contractor was not able to maintain required numbers of labors in site. Moreover, the required labors for the project were 58 but the contractor managed only 45 labors at site. The contractor had the project at other site too. So, it was also another reason behind low numbers of labors. Due to frequent rain during construction period there was a delay in work activities. As per client, the HAMS have to pay certain amount to bank as the interest. Delay of project means, client has to face the bank interest for delayed days too. So, client forced to prepare the tight schedule without considering the rain.Similarly, the floor height was of 11.5 feet as per design but the minimum height required for operation theaterwas 14 feet so, client changed the design of 11.5 feet floor height to 13 feet which caused delay in activities. Deficiency of steel pipes and clamps for scaffolding, ply board and steel rods for formwork and steel work was also the reason behind the delay. Moreover, poor working condition in double floor height level was also one of the reasons behind the delay of activities. The site engineer was not giving concrete decision about the drop slab provision so labors were not confidence in working which was also the reason behind delay. Moreover, the casting was done using two numbers of one bag mixture machine, during casting one of the machine was malfunctioned which caused delay in casting. Among these seven reasons, low numbers of labors and rain were the main reasons for the delay. Based on the literature, Akinsiku and Akinsulire [31], financial or cash flow difficulties, financial difficulties faced by contractors and public agencies, frequent change order and design, failure to pay for completed works, shortages of resources, considerable additional work, escalations of material prices, increases in the scope of work, delay in design work and late delivery of materials are the top ten causes of schedule overruns on construction projects however, this project illustrate different causes for schedule variation as low number of labors, rain, Change in design, deficiency of materials, poor working condition, non-confidence in workers, poor performance of machinery from direct observation.

\section{Variation in cost}

Quantity of item changed was calculated and it was multiplied by unit rate for variation in total cost.

Table-3: Quantity of the item changed with the associated cost

\begin{tabular}{|l|l|l|r|r|r|r|r|r|}
\hline S.N. & Work Items & Units & $\begin{array}{c}\text { Qty. as per } \\
\text { drawing }\end{array}$ & $\begin{array}{c}\text { Qty. as } \\
\text { per site }\end{array}$ & $\begin{array}{c}\text { Quantity } \\
\text { changed }\end{array}$ & Rate (Rs) & $\begin{array}{c}\text { Change in } \\
\text { Cost (Rs) }\end{array}$ & Remarks \\
\hline 1 & Steel Work & Kg & 69998.04 & 74871.33 & 3561.36 & 117.58 & 418745.17 & \\
\hline 2 & Concrete (M25) & Cu. ft & 6695.15 & 8515.43 & 1820.28 & 585.26 & 1065338.97 & \\
\hline 3 & Formwork & Sq. ft & 14215.67 & 16576.39 & 2360.72 & 77.91 & 183923.70 & \\
\hline & \multicolumn{7}{|c|}{ Total Excess in Cost } \\
\hline
\end{tabular}




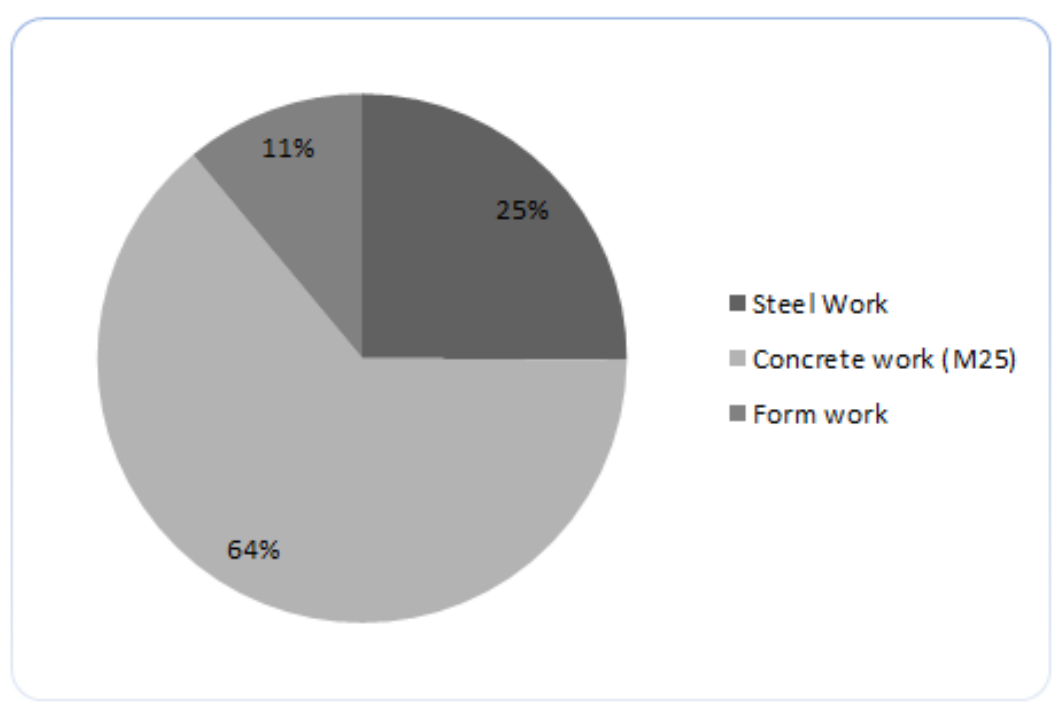

Fig-1: Contribution by work items in cost excess

The project was restarted after 2 years and existing steel in columns were rusted, so with consultations with experts, it was decided to continue the same column size up to second floor rather than smaller size columns as per designed for the upper floors. Another reason for excess in cost was due to increase in floor height by 1.5 feet in level 4 and Level 5 . The quantity of steel has been changed by 3561.36 $\mathrm{kg}$, quantity of M25 concrete by 1820.28 cubic feet and form work by 2360.72 square feet. Total excess in cost was $1,668,007.83$ rupees which is $12.58 \%$ of total cost. Based on the literature Olawale [52] identified 21 major factors causing cost overruns in construction projects are: design changes, incorrect evaluation of projects time and cost, risk and uncertainty related with projects, non- performance of subcontractors, conflict between project parties, fluctuation of rates, low skilled manpower, financing and payment, unstable interest rate, complexity of works, lack of proper training and experience of project manager, disagreement in contract documentation, lack of appropriate software, inflation of prices, contract and specification interpretation disagreement, dependency on imported materials, unpredictable weather condition, projects fraud and corruption, weak regulation and control and unstable government policies however, this project illustrate the cause for cost overrun as change in design from direct observation

Moreover, Koushki, [21] in a study in Kuwait, exposed that a cost overrun rate from $1 \%$ to $11 \%$ are more likely to occur on larger construction projects than smaller ones but cost overrun was of $12.58 \%$ in this project.

\section{Conclusions}

HAMS building construction project was taken as a case study for assessing the construction performance of building projects in terms of schedule and cost.. This project was restarted on 2017 March 28 after the halt of 2 years. This project was high rise building construction so it can represent a typical building construction project.

The proposed schedule of work was compared with the actual schedule of work progress. 14 work activities were delayed out of 23 activities. Total numbers of days delay was 16 days out of 80 days. The time overrun in the project was due to low numbers of labors, rain, change in design, deficiency of materials, poor working condition, non- confidence in workers, poor performance of machinery. Among all these reasons the main reasons for the delay of project were low numbers of labors and rain.

The steel of column got rusted since the project has stopped for 2 years, so the size of lower column was continued to upper two floors instead of smaller size and also floor height of 11.5 feet was changed to 13.0 feet. The two reasons were main factors for the change in estimated cost due to which there was cost overrun of NRs $1,668,004.824$. This is $12.58 \%$ higher than estimated cost.

\section{RECOMMENDATIONS}

- It is recommended to develop human resources in the construction industry through proper and continuous training programs about construction projects performance. These programs can update their knowledge and can assist them to be more familiar with project management, project quality, project time schedule and also safety provision of the project. In addition, it is preferred to develop and improve the managerial skills of engineers in order to improve performance of construction projects. All of that can be implemented by offering effective and efficient training courses in scheduling, cost, quality, safety, productivity, information systems and management of human 
resources. In addition, weather conditions must be studied for better performance in construction projects.

- Owners are recommended to plan well in advance so that the designs are not changed during construction. Changing design with time hampers the project performance. In addition, owner should facilitate payment to contractors in order to overcome delay, disputes and claims. Continuous coordination and relationship between project participants are required through project life in order to solve problems and develop project performance.

\section{ACKNOWLEDGEMENTS}

I would like to express my deepest thanks to all the helping hands without which this work would not have been completed. This research is dedicated to all the people affected from COVID 19 and hope the world is going to come over this problem. Great Salutation to medical professionals and security people.

\section{REFERENCE}

1. Chitkara, K.K. (2011). Construction Project Management - Planning, Scheduling and Controlling. 2nd ad.Tata McGraw Hills.

2. Navon, R. (2005). Automated Project Performance Control of Construction Projects, Automation of Construction, 14, 467-476.

3. Puspasari, K., Rusli, F., \& Mileiva, S. (2005). Formulasi Campuran Flower Leather dari Bunga Mawar Dengan Ekstrak Rempah-Rempah (Cengkeh dan Kayumanis) sebagai Pangan Fungsional Kaya Antioksidan. Laporan Penelitian.

4. Ogunlana, S. O. (1996). Constructiondelays in a fast-growing economy: comparing Thailand with other economies.International Journal of Project Management, 14(1), pp.37-45.

5. Cheng, M.Y. (2011). Evaluating Subcontractors Performance Using Evolutionary Fuzzy Hybrid Neural network. International Journal of Project Management, 29, 249-356.

6. Acuna, M. I. (2000). Reducing time in the construction of high rise building [Online] Available at: dspace.mit.edu [Accessed on June 2017].

7. Holmes, D. G., \& Lipo, T. A. (2003). Pulse width modulation for power converters: principles and practice (Vol. 18). John Wiley \& Sons.

8. NFPA. (2017). National Fire protection Association (NFPA). Available at: www.nfpa.org [Accessed June 2017]

9. DUDBC. 2017. Kathmandu, Nepal: Department of Urban Development and Building Construction (DUDBC). Available at: dudbc.gov.np [ Accessedon June 2017]
10. drrportal. 2017. Kathmandu, Nepal: Nepal Disaster Risk reduction portal (drrportal), Available at: drrportal.org.np [ Accessed on June 2017]

11. Assaf, S.A., \& Al-Hejji, S.A., (2006). Causes of delay in large construction projects.International Journal of Project Management, 24, 349-357.

12. Frimpong, Y. (2003). Causes of delay and cost overruns in construction of groundwater projects in a developing countries; Ghana as a case study. International Journal of Project Management, 21, 321-326.

13. Kaliba, C. (2009). Cost escalation and schedule delays in road construction projects in Zambia.International Journal of Project Management, 27, 522-531.

14. Enshassi, A. (2009). Delays and cost overruns in the construction projects in the Gaza Strip.Journal of Financial Management of Property andConstruction, 14(2), 126-151.

15. Flyvbjerg, B. (2003). How common and how large are cost overruns in transport infrastructure projects?. Transp. Rev, 23(1), 71-88

16. Wael, A. (2007). The significant factors causing delay of building construction projects in Malaysia, Engineering. Construction and Architectural Management, 14(2), 192-206.

17. Angelo, W.J., \& Reina, P. (2002). Megaprojects need more study up front to avoid cost overruns, Mc Graw Hill Construction.

18. Kaming, P. (1997). Factors influencing construction time and cost overruns on high-rise projects in Indonesia, Construction Management Economics, 15(1), pp.83-94

19. Ameh, O. (2010). Significant factors causing cost overruns in telecommunication project in Nigeria. Journal of Construction in Developing Countries, 15(2), 49-67.

20. Al-Momani, A., (1996). Construction cost prediction for public school buildings in Jordan.Construction management and Economics, 14, 311-317.

21. Koushki, P. A. (2005). Delay and cost increase in the construction provate residential in Kuwait, Construction Mang\& Economics, 23, 285-294.

22. Jahren, C., \& Ashe, A. (1990). Predictors of cost overrun rates. Journal of Construction Engineering Management ASCE, 116(3), 548-552.

23. Yates, J. K., \& Epstein, A. (2006). Avoiding and minimizing construction delay claim disputes in relational contracting. Journal of professional Issies in Engineering Education and practice, 132(2), 168-179.

24. Rabbani, M. R. (2011). A biography of Pakistani federalism: unity in diversity. Leo Books.

25. Bramble, B. B., \& Callahan, M. T. (2010). Construction Delay Claims. 4th ed. USA: Wolters Kluwer Law \& Business.

26. Al-Kharashi, A., \& Skitmore, M. (2009). Causes of delays in Saudi Arabianpublic sector construction 
projects. Construction Management and Economics, 3-23.

27. Sriprasert, E. (2000). Assessment of Cost Control System: A Case Study of Thai Construction. M.S. thesis, Bangkok: Asian Institute of Technology

28. Battaineh, H., (1999). Information system of progress evaluation of public projects in Jordan. MSc thesis, Civil Engineering department, JO rdanuniversity of science and technology.

29. Haseeb, M. (2011). Problems of projects and effects of delays in the construction industry of Pakistan. Australian Journal of Business and Management Research, 1(5), pp.41-50.

30. Ade-Ojo, C. O., \& Babalola, A. A., (2013). Cost and Time performance of construction projects under the due process reform in Nigeria. Research Inventy: International Journal of Engineering and Science, 3(6).

31. Akinsiku, O. E., \& Akinsulire, A. (2012). Stakeholders' Perception of the Causes and Effects of Construction Delays on Project Delivery. Journal of Construction Engineering and Project Management.

32. Ali, A. S. (2012). Contractors' perception of factors contributing to project delay: case studies of commercial projects in klang valley, Malaysia.

33. Memon, A.H. (2012). Time and Cost Performance in Construction Projects in Southern and Central Regions of Peninsular Malaysia. International Journal of Advances in Applied Sciences, 1(1), 4552.

34. Pourrostam, T., \& Ismail, A. (2011). Significant Factors Causing and Effects of Delay in Iranian Construction Projects. Australian Journal of Basic and Applied Sciences, 5(7), pp.450-456.

35. Al-Gharbi, M. S., Jing, X., Kraaijveld, M., Hognestad, J. B., \& Udeh, P. O. (2007, January). SCAL relative permeability measurements and analyses for a cluster of fields in South Oman. In International Petroleum Technology Conference. International Petroleum Technology Conference.

36. Al-Momani, A. H., (2000). Examining service quality within construction processes, Technovation, 20, 643-651.

37. Faridi, A., \& El-Sayegh, S., (2006). Significant factors causing delay in the UAE construction industry, Constuction Management and Economics, 24(11), 1167-1176.

38. Sambasivan, M., \& Soon, Y. (2007). Causes and effects of delays in Malaysian construction industry. International Journal of Project Management, 25(5), 517-526.

39. Walker, D.H.T. (1995). An investigation into construction time performance. Construction Management and Economics, 13(3), 263-274.
40. Kumaraswamy, M.M., \& Chan, D.W.M. (1998). Contributors to construction delays. Construction Management and Economics, 16(1), 17-29.

41. Al-Momani, A. H., (2000). Construction delays: A quantitative analysis. International Journal of Project Management, 18(1), 51-59.

42. Jaskowski, P., \& Biruk, S. (2011). The conceptual framework for construction project risk assessment reliability. Theory \& Applications, 2.

43. Shebob, A. (2012). Comparative study of delay factors in Libyan and the UK construction industry. Engineering, Construction and Architectural Management, 19(6), pp. 688-712.

44. Morris, S. (1990). Cost and time overrun in public sector project. Economic and political weekly, 47,154-68.

45. Elinwa, U., \& Buba, S. (1993). Construction cost factors in Nigeria. Journal of construction engineering and management, 119(4), 698-714.

46. Flyvbjerg, B. (2002). Under estimating cost in public work project.Journal of the American planning association, 30, 31- 44

47. Bubshait, A. A., \& AL-Juwairah, Y. A. (2002). Factors contributing to construction costs in Saudi Arabia. Cost Engineering, 44(5), 30.

48. Jackson, S. (2002). Project cost overruns and risk management in Greenwood, proceedings of association of researches in construction management 18th annual ARCOM conference, New castle , Northumber university, UK, 2nd -4th September.

49. Omoregie, A., \& Radford, D. (2006). Infrastructure delays and cost escalation: Causes and effects in Nigeria. Proceeding of sixth international post graduate research conference, 3rd, 7th April Delft University of technology and TNO, the Netherlands.

50. Le-Hoai, L. (2008). Delay and cost overruns in Vietnam large construction projects: a comparison with other selected countries. KSCE J. civil engineering, 12(6), 367-377.

51. Ali, A.S., \& Kamaruzzaman, S.N. (2010). Cost performance for building construction projects in klang valley. Journal of Building Performance, l(1).

52. Olawale, Y.A. (2010). Cost and time control practice of construction projects in the UK. The Pursuit of effective management control.University of the West of England.

53. Durdyev, S. (2012). Factors causing cost overruns in construction of residential projects; case study of turkey. International Journal of Science and Management.

54. Kasimu, M.A. (2012). Significant factors that causes cost overruns in building construction projects in Nigeria. J. Contemporary research in business, 3(11). 